\title{
解 説
}

\section{アルミニウム合金の電磁鋳造法とその鋳塊の 品質特性について}

\section{三田村 康二*}

Continuous casting of aluminum alloys in electromagnetic field

MITAMURA Koji*, SUGISAKI Hideo* and AOYAMA Takashi*

\section{1. まえがき}

アルミニウムおよびその合金の加工用鋳塊の製造には 半連続鋳造法(Direct-Chill 法, 以下 D.C. 法と略す) が 常用されている。このD.C.法はアルミニウムに関して は, 1930年代に確立され, 以来生産性の向上あるいは鋳塊 の品質向上を目指して多くの改良が成されてきている。 この方法の概略は金属製の水冷鋳型（通常はアルミニウ ムまたは銅が使用される）に溶湯を連続的に注入し，鋳 型による 1 次冷却（間接冷却）と鋳型下の冷却水による 2 次冷却（直接冷却）により鋳塊を凝固させ，鋳型下部 より連続的に引き出すもので1),2)，溶湯は鋳型との接触 によつて物理的に保持される。

一方，近年ソ連に㧍いて，このような水冷鋳型を用い ずに電磁力を利用して溶湯を保持しつつ鋳造するプロセ ス（電磁鋳造法, 以下電磁法と略す）が開発された。こ の技術は今までのD.C.法とは原理的に全く異なるもの で, 溶湯は鋳型と接触せず直接水冷されて凝固するため, 得られる鋳塊は種々の特徵的な性質をもつている。当社 もこの新技術に注目し，昭和 47 年に技術導入を行ない， 現在実用規模の試験鋳造設備を稼動している。そこでこ の機会に，今まで紹介解説された文献や3) 8) 当社でのテ スト結果に基づき, 電磁法の概要について述べてみた い。

\section{2. 電磁法の原理}

\section{1 電磁法の基本原理}

金属の溶解保持あるいは移動等に電磁場を応用するこ とは広く知られている ${ }^{9)}$ 11)。例えば，低周波誘導炉によ る溶解, 電磁ポンプによる溶湯輸送, るつぼと接触させ ず金属を浮遊溶解するレビテーション溶解法" ${ }^{9}$ 等がこれ に相当する。
通常, 導電体の周囲に交番高周波電流 $I_{1}$ が流れると その回りに磁場 $H$ ができ，導電体には $I_{1}$ と逆位相の渦 電流 $I_{2}$ が誘導される。この磁場と渦電流の相互作用に よりフレミングの左手の法則に従ら電磁力 $F$ が生まれ る。これが電磁法の基本原理である。これらの関係を概 略的に第 1 図に示す。この基礎理論は金属中に吸収され る電磁波に関するもので, 電磁力の大きさは式(1) (4)の マックスウェルの電磁方程式 ${ }^{12)}$ をえられた境界条件の もとで解くことによつて得られる。

$$
\begin{aligned}
\operatorname{rot} \vec{H} & =\stackrel{j}{j}+\frac{\partial \vec{D}}{\partial t} \\
\operatorname{div} \vec{B} & =0 \\
\operatorname{rot} \vec{E}= & -\frac{\partial \vec{B}}{\partial t} \\
\operatorname{div} \vec{D}= & 0 \\
\text { ただし } & \vec{H}: \text { 磁界 } \\
& j: \text { 電流密度 } \\
& \vec{D}: \text { 電気変位 }
\end{aligned}
$$

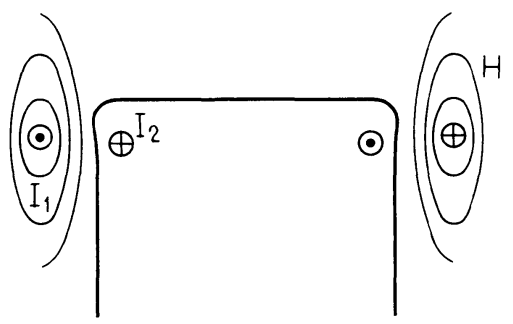
$I_{1}: 1$ 次電流
$\mathrm{I}_{2}$ : 渦電流
H: 碃界
$F$ : 電磁力

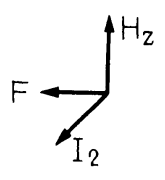

第 1 図電磁力発生状況 


\section{$\vec{B}:$ 磁束密度 \\ $\vec{E}:$ 電界}

この理論に基づき，ソ連で電磁法が開発され，さらに諸 外国でも技術導入が成されて現在種々の研究検討が取り 進められている。

\section{2 電磁鋳型の構造と鋳造法}

鋳型概略図を第 2 図に示す。鋳型はインダクター，ス クリーン，ケーシングと呼ばれる 3 つの部分から構成さ れている。

インダクターは中空の導電体リング（内部水冷）でこ の部分に高周波電流が流れ，溶湯を保持する力(電磁力) を生み出す，言わば電磁法の中心となるものである。こ の際の周波数は溶湯中に誘起される渦電流の浸透深さに 関係し，各種因子を考慮してその値が選定される。ある 特許 ${ }^{20)}$ によれば，ビレットの場合には鋳塊半径と浸透深 さの関係が式(5)を満足するように周波数が決められるべ きだとされている。

$$
\begin{aligned}
& \frac{R \sqrt{2}}{\Delta l} \geq 10 \\
& \text { ただし } \quad \begin{array}{l}
R: \text { 鋳塊半径 } \\
\Delta l: \text { 渦電流の浸透深さ }
\end{array}
\end{aligned}
$$

このインダクターはD.C.法の水冷鋳型に相当し, この 形状が鋳塊の形状を決定する。そして, 鋳塊の断面寸法 は電磁力と溶湯静圧の均衡によつて決まる。電磁力と溶 湯静圧の平衡状態は式(6)で表わすことができる。

$$
\begin{aligned}
& \rho g h=K I_{1}{ }^{2} \\
& \text { ただし } \quad \rho: \text { 金属密度 } \\
& g: \text { 重力加速度 } \\
& h: \text { 溶湯高さ (第 } 3 \text { 図参照) } \\
& k: \text { 装置の幾何学的寸法と金属の導 電率 } \\
& \text { と電流の周波数を考慮に入れた 係数 } \\
& I_{1}: \text { インダクター電流 }
\end{aligned}
$$

つまり，電磁力はインダクター電流の 2 乗に比例し, 溶 湯静圧は当然ながらその溶湯の高さに比例する。よつ て, 電磁法では所定の断面寸法が得られるよう，インダ クター電流, メタルレベルを厳密に設定しなければなら ない。(なお，D.C.法による鋳塊の断面寸法は，水冷

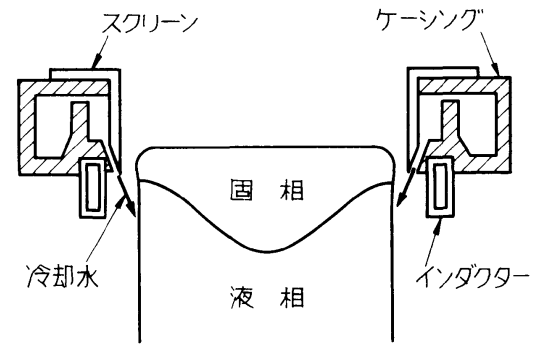

第 2 図 電磁鋳型概略図
鋳型の寸法によつて自ら決定される。通常はインダクタ 一断面の中心線すなわち最も磁界強度の高い位置と鋳塊 外周部の固液界面の位置とを一致させるような鋳造条件 が最も安定した鋳造を可能にすると言われている。なぜ なら, このインダクターの中心線付近が最も磁界分布が 均一であるからである。また, インダクター中心線より 下部では発生する電磁力より溶湯静圧の方が勝るため, この部分は凝固殼を形成させることによつて溶湯を保持 する必要がある。

スクリーンは非磁性金属から作られ，横断面において その厚さが上方に向かつて増大しており，磁場を鋳型内 で局部的に遮蔽し，鋳塊の所定寸法が得られるようにす る目的をもつ。スクリーンを設置しない場合の鋳型内で の垂直方向（鋳造方向）の電磁力と溶湯静圧の関係を第 3 図に示す。溶湯静圧は上方へいくに従い，式(6)により その高さに比例して減少していく。一方, 電磁力は上方 へいくに従い直線関係からずれるため, 上方では電磁力 が溶湯静圧より大きくなり, 溶湯の形状が不安定になり やすい。このため上方に向かつてその厚さが増大するス クリーンを設置してこの電磁力の垂直方向の分布を直線 に近づけ，安定した鋳塊寸法を得ることができる。言い 換えれば，このスクリーンの存在が安定鋳造を確立させ たと言えよう。また，鋳塊に供給される冷却水はスクリ ーンの内壁に沿つて流出する。よつて, スクリーン位置 は最適な磁界遮蔽と最適な冷却水供給位㯰を満足するも のでなければならない。

ケーシングは非導電物質から成り鋳型の外枠となるも ので，その内部は冷却水のヘッダーとして使用される。 このように所定の鋳塊を得るためには, インダクターの 高周波電流による磁界と溶湯内に誘起される渦電流の相 互作用, スクリーンによる磁界の局部遮蔽, 冷却水によ る凝固款の形成の 3 つの因子を最適に組み合わせる必要 がある。

鋳型構造については現在まで各種の改良が成されてい る $^{13) \sim 21)}$ 。 2,3 の具体例を第 4 図に示す。(a)はスクリー ンの内側に導電性の高い金属から成るリングを同軸配置

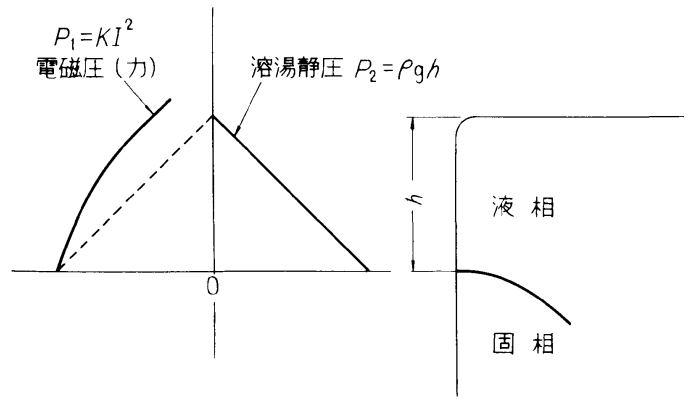

第 3 図鋳型内での電磁圧（力）と溶湯静圧の関係 
し，鋳造温度の低下に伴う強い溶湯の動きに起因する鋳 塊表面欠陥の発生を防止して寸法精度の向上を計るもの である ${ }^{13)}$ 。この他，寸法精度向上を目的とするもので は, 溶湯のレベル変動を検知し,インダクター電流に作 用する電気信号に変更することによつて，一定の寸法值 を与えるものがある ${ }^{19}$ 。電磁法では, レベル変動に伴つ て鋳塊寸法が変化するのでレベル管理が重要である。(b) は ${ }^{21)}$ 鋳塊への冷却水供給口をスクリーン内壁とは別に設 け，その冷却水を鋳塊に直角に当て，さらにその当たる 位置を変化可能としたもので，電磁界の最適分布と冷却

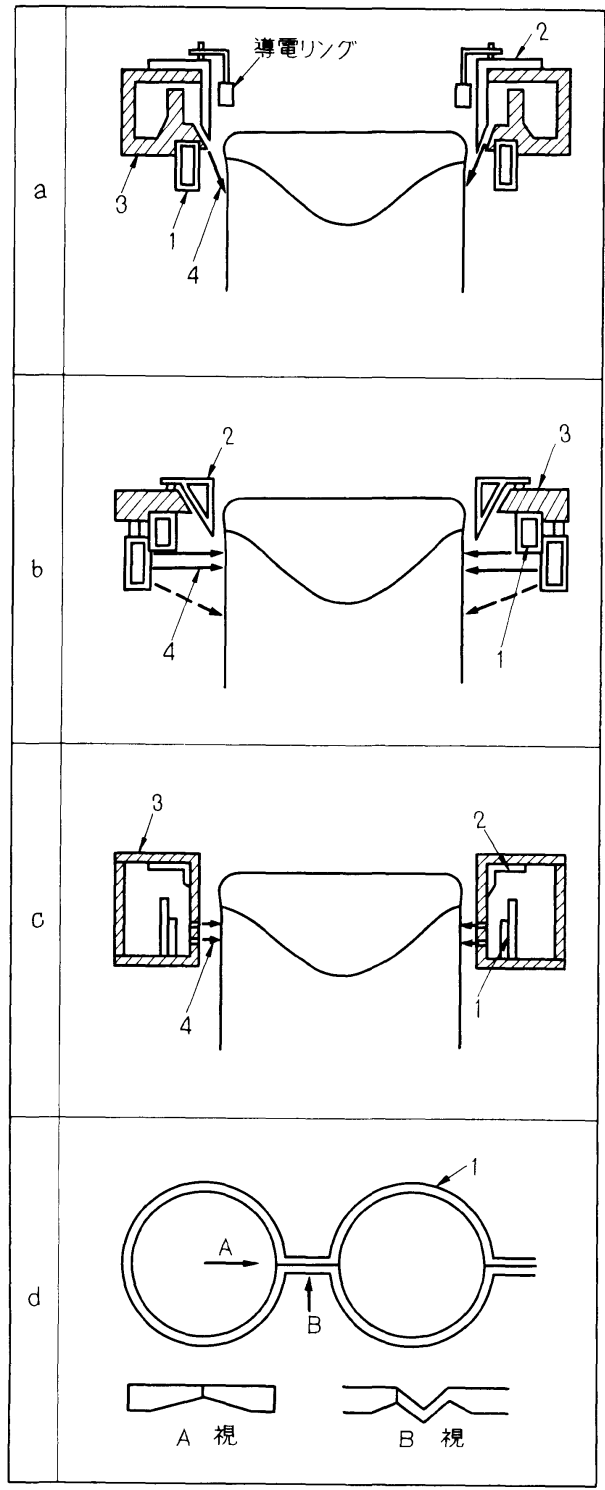

1:インダクター

$2:$ スクリーン

$3:$ ケーシング

$4:$ 冷却水

第 4 図 改良電磁鋳型の例
水の最適供給位置を同時に確保することが困難な場合に 有効である。(c)は潘)インダクターとの偶然の接触の可能 性を除去した安全面の考慮, および鋳型製造の単純化, コンパクト化を目的とし，インダクター，スクリーンは ケーシングの内部に含まれる形となつている。安全面に 関しては，鋳塊形状が大きくインダクター長さが長くな るものについてインダクターを 2 分割し，個々のインダ クターへの付加電圧を降下させるものも見られる ${ }^{14)}$ 。(d) は $^{18)}$ インダクター形状に関連するもので，給電部では磁 界が不均一に成りやすいため，その形状を局部的に変更 して鋳塊周囲にわたり均一な磁界を発生させるょうにし ている。

このような電磁鋳型を使用した鋳造法自体はD.C.法 と特に差異はない。まず，鋳型内所定位置にボトムがセ ットされインダクターに高周波電流が流される。冷却水 はケーシング内部のヘッダーよりスクリーン内壁に沿つ て流れ，スタート時にはボトムに当たつている。次に， トラフ，ディストリビューターを通過して溶湯がボトム 上にフィードされる。鋳型内にはフロートがあり，溶湯 流量を調節し，鋳型内での溶湯レベルを一定に保つ。溶 湯レベルが所定の高さに達したらボトム降下が開始され る。この降下に従い, 冷却水が直接鋳塊に供給され鋳塊 を冷却凝固し，連続的に鋳造が実施されることになる。

電磁力によつて溶湯を保持造形する電磁法の他に, 最 近，日本特許では222,23) 溶湯の表面張力あるいはガス， 圧空を利用することによつて鋳型と非接触のD．C.法が 見られるので，合わせて紹介しておく。第 5 図に表面張 力を利用した鋳造法を示す22)。この方法によれば，溶湯 上部では溶湯静圧を溶湯の表面張力にて均衡させ，下部 では冷却水による凝固殻を形成して溶湯を保持するもの で，溶湯と鋳型間の距離は $1 \mathrm{~mm}$ 弱としている。また，

第 6 図に示すガス，圧空方式はこの表面張力の代わりに ガスまたは圧空を溶湯表面に吹き付けることにより溶湯 を保持しつつ鋳造するものである ${ }^{23)}$ 。いずれにせよ， 2 つの方法とも電磁法と同様鋳塊表皮部の品質向上を目的 としている。

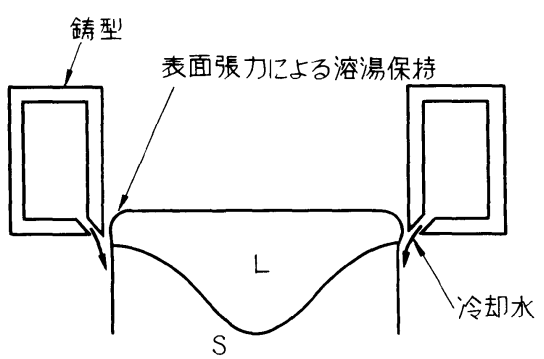

第 5 図 表面張力を利用した溶湯一鋳型非接触鋳造法 


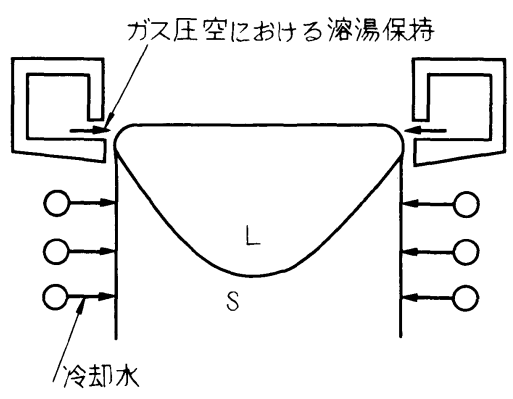

第 6 図 ガス, 圧空を利用した溶湯一鋳型非接触鋳 造法

\section{3. 電磁法と D. C. 法}

電磁法はD.C.法に対してどのような点が特徵的であ ろらか? 第 7 図に電磁鋳型, D.C.鋳型での冷却 状 態, 凝固形態の相異を示す ${ }^{6)}$ 。 D.C.鋳型での冷却ゾー ンを次の 4 つに分けることができる。つまり，ゾーン 1 は溶湯の表面張力で保持される空冷部分であり，ゾーン 2 では水冷鋳型と接触して薄い凝固殼が形成される。し かし，ゾーン 3 では鋳塊の凝固による熱的収縮のため， 凝固殼は鋳型を離れエヤーギャップを生成し，再度空泠 となり鋳塊冷却速度が著しく低下する。引き続き，ゾー ン 4 では鋳塊への直接水冷により凝固が進行する。ここ で，ゾーン $2 ， 3$ とはカイザー社の ${ }^{24)}$ 報告による鋳型冷 却長さと同一であり，ゾーン 4 は直接水冷の効果が及ぶ

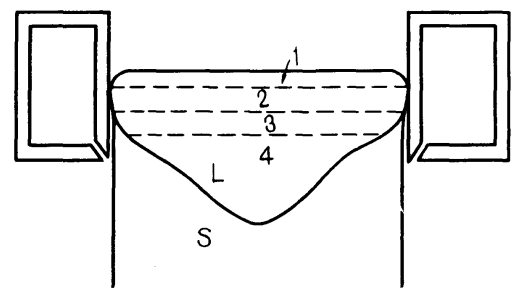

(a) I). (:)

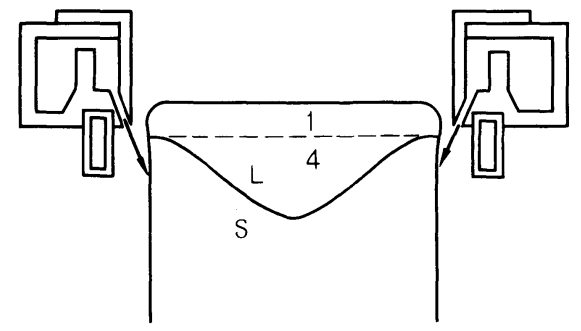

（b）兠磁鋳型

1. 空椧部

2. 鋳型との接触による 1 次冷却部

3. 空冷部（エヤーギャップ生成部）

4. 直接水冷による 2 次冷却部

第 7 図 D G 鋳型および電磁鋳型による冷却状態の 相異
距離つまりスプレー冷却距離と同一である。D.C.法で はこのような工程を経て凝固が完了するため, 鋳塊表皮 部ではその鋳型様式からくる不可避の欠陥，例えば，焼 付, 発汗, 逆偏析が発生する。

焼付とは，衆知のように，溶湯と固体金属鋳型との接 触による物理的な摩擦あるいは癒着により生じた鋳造才呵 向に平行なスジ状の欠陥である。この焼付には鋳型内壁 の整備の良否が大きな影響を及ぼすことが経験的に知ら れており，現状では鋳造前の鋳型内壁整備や内壁への潤 滑剂の塗付により，可能な限り焼付の発生を防止してい る。

発汗は，エヤーギャップの生成による鋳塊冷却速度の 低下のために表皮凝固殼が再加熱され, 粒界の低融点化 合物が融解して鋳塊表面に浸出し，一見汗のようになつ たものである。凝固温度範囲が広く固相線温度が低い合 金系では，この再溶融がさらに顕著で，表面が激しい凹 凸となることがしばしばある。一方，1100程度の比較的 低濃度の材質であれば, 軽度の周期的発汗として現われ ることが知られている12,25)。これについては，最近では 小菅, 水上の研究が26)あり, ゾーン 3 において低融点化 合物の溶融により凝固殻は容易に外側に変形し，再び鋳 型に接触して急冷され収縮するという現象を繰り返すこ とにより周期的発汗が観察されるとしている。

逆偏析はアルミニウム合金の D.C. 鋳塊では一般的 に見られ，衆知のよ5に，表皮部で溶質濃度が高くな $3^{27), 28)}$ 。これは，いうまでもなく上述の発汗現象と相関 関倸をもつている。さらに第 8 図で説明する表皮部のズ ンプ形状にも影響を受けるものと思われる。

一方，電磁鋳型を使用した場合には，第 7 図(b)から明 らかなよらに冷却ゾーン 2,3 がないため鋳型との接 触, エヤーギャップの生成による欠陥を完全に排除でき る。

では，このように泠却条件が異なる 2 つの鋳造法での 鋳塊表皮部のズンプ形状に着目してみよう。第8 図にそ の模式図を示す。D.C.法では鋳型壁による1次冷却， 冷却水による 2 次冷却, その間に存在するエヤーギャッ プにより表皮部ズンプは急勾配となる。この形状は鋳造 速度等の因子にも影響を受ける。電磁法では冷却水によ る直接水冷のみのため, 表皮部ズンプは D.C.法に比し フラットとなることが予想される。Altenpohl'29),30) によ れば鋳塊の凝固速度は界面進行速度としてとらえること ができ，この速度は組織等に密接に関係するとしてい る。第 8 図に従い, ズンプ各位置での凝固速度を考えて みよう。例えばビレットの場合には，そのズンプ先端で 凝固速度は鋳造速度と同一となり, A 点では $V=V c \sin$ $\alpha$ となる。ここで， $V$ は凝固速度， $V c$ は鋳造速度， $\alpha$ はズンプの角度である。また，スラブの場合には，点 


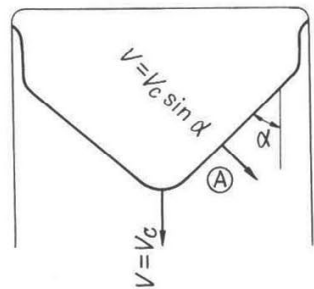

(a) D. G，法によるズ ンプ形状

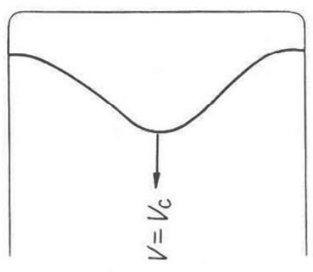

(b) 電磁法によるズンプ 形状
$V_{C}$ : 鋳造速度 $\quad V$ : 凝固速度 $\quad \alpha$ : ズンプ角度

第 8 図 D.C.法電磁法によるズンプ形状の相異

対称ではないのでさらに複雑になるが，傾向としては変 わりはない。このような表皮部ズンプの勾配からすれば 表皮部での凝固速度はD.C. 法で遅く, 電磁法で速いと 言える。この表皮部での凝固速度の差は品質に大きな影 響を及ぼすことは明らかであり，鋳塊表皮部品質改善に 対し電磁法は有効な手段と考えられる。

\section{4. 品質特 性 ${ }^{312}$}

現在まで, 電磁設備を使用して種々の材質, 鋳塊サイ ズのスラブ，ビレットを鋳造した結果，D.C.法で鋳造 可能なものはすべて可能との見通しを得ている。そこ で,この章では当社におけるテスト結果に基ゔき, 電磁 品, D. C. 品比較の形で鋳塊の品質特性について説明す る。なお，テストに供した鋳塊の化学組成は第 1 表に示 すとおりである。

\section{1 外観}

写真 1 に1050スラブ $(400 \times 1,320)$ の外観写真を示す。 D. C. 品湔章で述べたとおり特有の周期的発汗が発生 しているが，電磁品は滑らかな外観を呈している。ま た，写真 2，3に2014，7075ビレット $(500 \phi)$ の外観を 示す。D.C.品2014には激しい発汗を生じ，7075では焼 付が見られる。しかし，電磁品は極めて滑らかな外観で あり，溶質濃度の高い合金系では電磁品，D．C.品の差 が顕著である。通常, D.C.法ではその材質, 主に凝固 温度範囲に応じた特有の外観が観察されるが，電磁法で
は材質が異なつても外観にほとんど差異がないことがわ かる。この鋳塊外観が良好なことは電磁法の特徴の 1 つ といえる。

\section{2 マクロ組織}

アルミニウム鋳塊に現われるマクロ組織は, 表皮より 内部に向かつて, チル晶, 柱状晶, 粒状晶（粒度が異常 に大きい粗大晶を含む）の順となり，この他，特有の羽

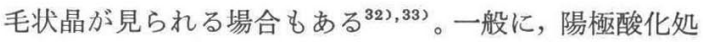
理性のきびしい品質に対しては, 内部組織は均一微細な 粒状晶が良く, 羽毛状晶, 粗大晶は好ましくないと言わ れている。写真 4 にマク口組織の代表例として1050スラ ブ $(400 \times 1320)$ の横断面組織を示す。電磁品， D. C. 品 とも羽毛状晶, 粗大晶の発生は見られず, 全体的には均 一な組織と見ることができる。しかし，表皮部に着目す ると写真 5 のごとく, D. C. 品にはチル晶と呼ばれる微

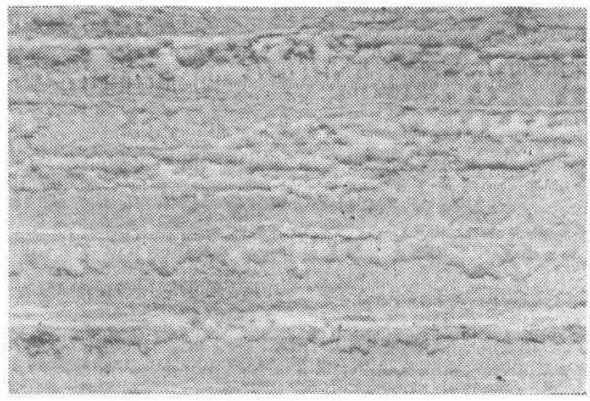

(a) D. C. 品

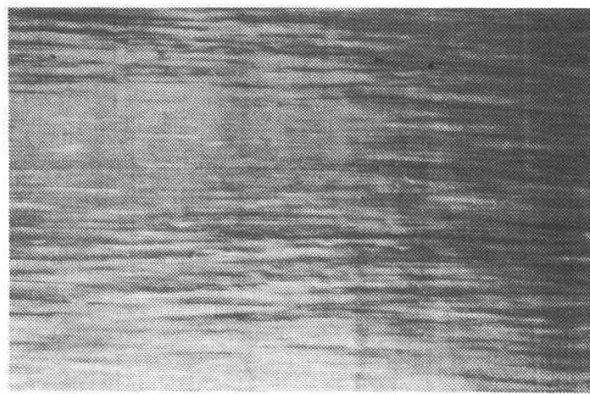

(b) 電磁品

$(\times 1 / 2)$

写真 11050 スラブ外観

第 1 表 供試材 化学組 成

(wt \%)

\begin{tabular}{|c|c|c|c|c|c|c|c|c|c|c|}
\hline 材質 & 鋳塊サイズ $(\mathrm{mm})$ & $\mathrm{Cu}$ & $\mathrm{Si}$ & $\mathrm{Fe}$ & $\mathrm{Mn}$ & $\mathrm{Mg}$ & $\mathrm{Zn}$ & $\mathrm{Cr}$ & $\mathrm{Ti}$ & $\mathrm{Al}$ \\
\hline 1050 & $400 \times 1320$ スラプ & $\begin{array}{l}0.01 \\
\sim 0.02\end{array}$ & $\begin{array}{l}0.11 \\
\sim 0.12\end{array}$ & $\begin{array}{l}0.28 \\
\sim 0.30\end{array}$ & 0.00 & 0.00 & 0.00 & 0.00 & 0.03 & $\leq 99.5$ \\
\hline 2014 & $500 \phi \quad ヒ ゙ レ ッ ト$ & $\begin{array}{l}4.5 \\
\quad \sim 4.6\end{array}$ & $\begin{array}{l}0.72 \\
\sim 0.79\end{array}$ & $\begin{array}{l}0.24 \\
\sim 0.26\end{array}$ & $\begin{array}{l}0.82 \\
\sim 0.85\end{array}$ & $\begin{array}{l}0.64 \\
\sim 0.67\end{array}$ & 0.00 & 0.00 & $\begin{array}{l}0.02 \\
\sim 0.03\end{array}$ & $\mathrm{R}$ \\
\hline 7075 & $500 \phi \quad$ ビレット & 1.5 & $\begin{array}{l}0.08 \\
\sim 0.09\end{array}$ & $\begin{array}{l}0.25 \\
\sim 0.26\end{array}$ & 0.09 & $\begin{array}{l}2.5 \\
\sim 2.6\end{array}$ & $\begin{array}{l}5.7 \\
\sim 6.1\end{array}$ & $\begin{array}{l}0.21 \\
\sim 0.22\end{array}$ & $\begin{array}{l}0.05 \\
\sim 0.06\end{array}$ & $\mathrm{R}$ \\
\hline
\end{tabular}




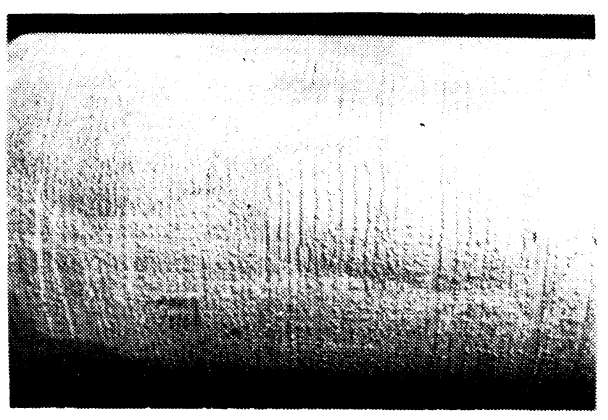

(a) I). C. 品

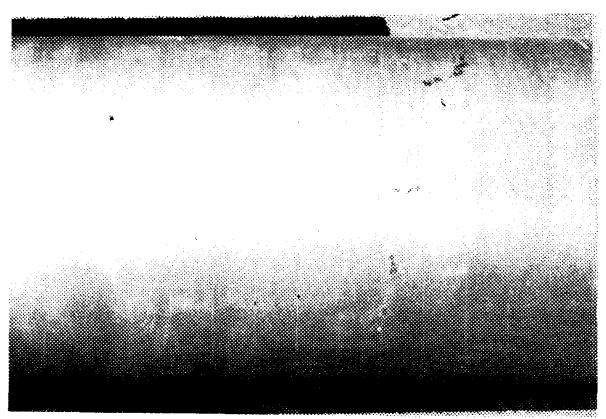

(b) 霆磁只

$(\times 1 / 13)$

写真 22014 ビレッ卜 (500@) 外锥

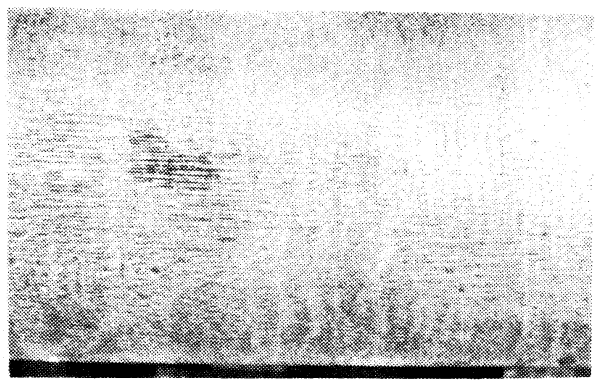

(a) D. C. 品

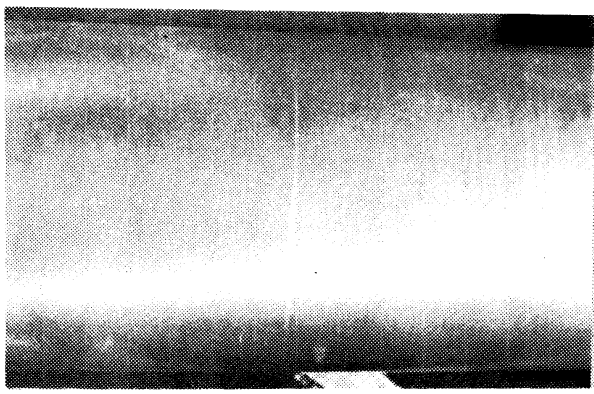

(b) 霆磁品

$(\times 1 / 13)$

写真 37075 ビレット $(500 \phi)$ 外観

引。

\section{5 機械的性質}

第11図に2014ビレット径方问の機械的性質（引张強 さ, 耐力, 俳ざ, シャルピ一衝撃值）の分布を示す。試

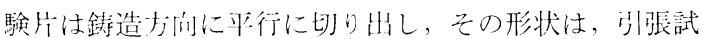
験についてはJIS 4 品, シャルピ一衝撃試験については JIS 3 号在採楜た。な㧍，供試材は第 2 表の7075ビレ

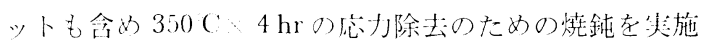
している。ミクロ組織むるいは作析状況に対応して，表

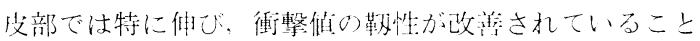

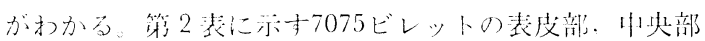
のテスト結果でも同様な傾问が見ら机，表皮部ではやは り勒性が间上している。しかし，肚部に执いては，陑 材啠其電磁山，D，C．品で大きな有意差は見られない。

以上のように，菴磁品怄D。C，品に比し，表皮部の品 質が良好であることが湖碓よなつた。通常，D．C.品を

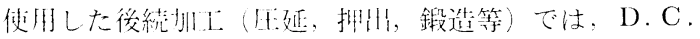

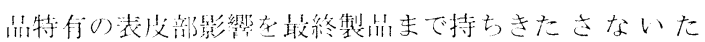

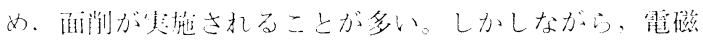

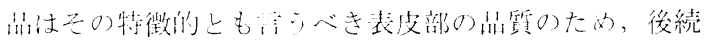

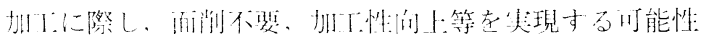
在もつている。 


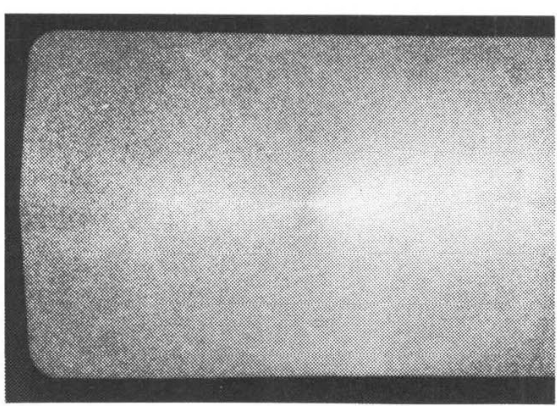

(a) D. C. 品

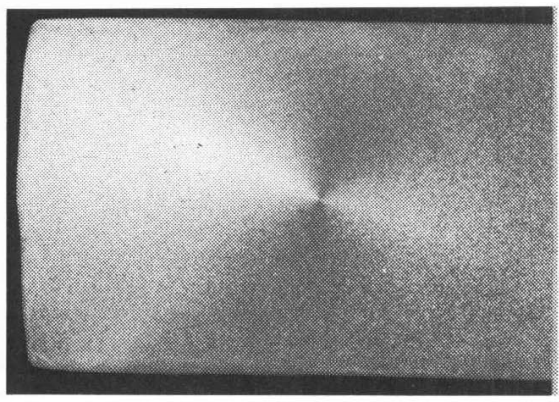

(b) 電磁品

$(\times 1 / 10)$

写真 4 1050スラブ $(400 \times 1320)$ マクロ組織

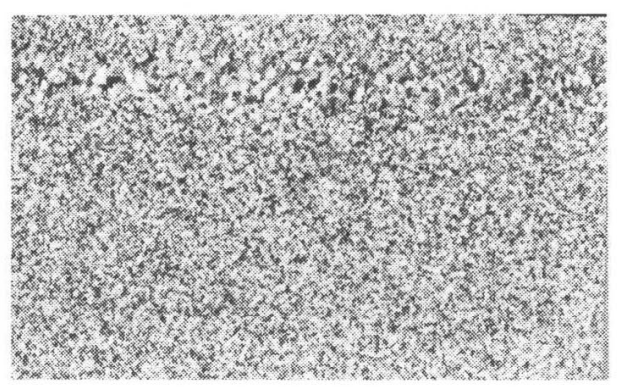

(a) D. G. 品

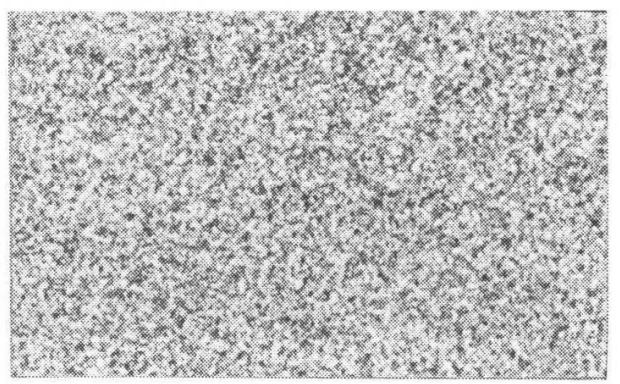

(b) 電磁品

$(\times 1)$

写真 5 1050スラブマクロ組織
1050スラブ

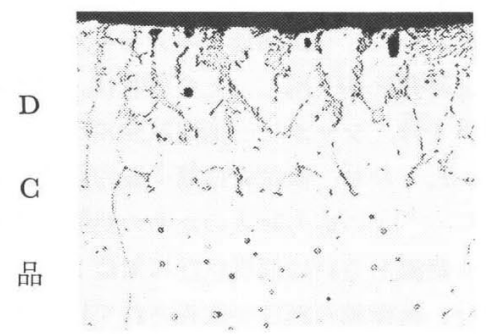

電

磁

品

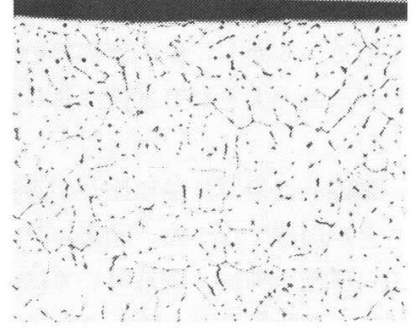

$(\times 100)$
2014ビレット
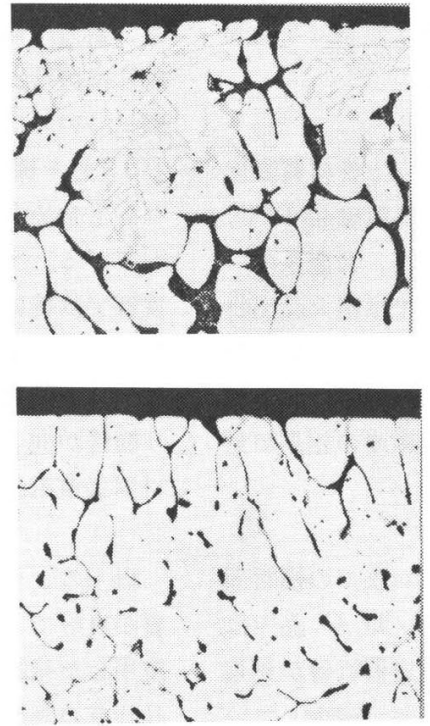

$(\times 200)$
7075ビレット
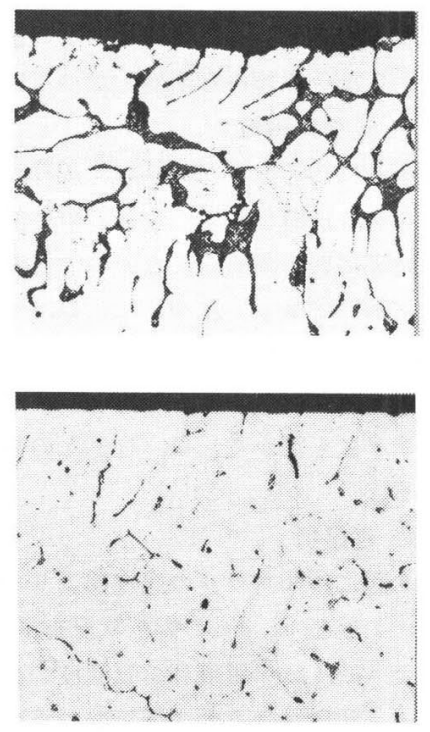

$(\times 200)$

写真 6 D C 鋳造, および電磁鋳造の1050スラブ，2014ビレット，7075ビレットのミクロ組織 
第 2 表 7075-500 $\phi$ ビレット機械的性質

\begin{tabular}{|c|c|c|c|c|c|c|c|c|}
\hline \multirow[b]{2}{*}{ 機械的性質 } & \multicolumn{2}{|r|}{ 電 } & 磁 & 品 & \multicolumn{2}{|r|}{ D. } & C. & 品 \\
\hline & & 皮 部 & 中 & 央 部 & & 皮 部 & & 央 部 \\
\hline 引張強さ $\left(\mathrm{kg} / \mathrm{mm}^{2}\right)$ & & 21.5 & & 11.8 & & 21.2 & & 15.9 \\
\hline $0.2 \%$ 耐力 $\left(\mathrm{kg} / \mathrm{mm}^{2}\right)$ & & 9.0 & & 8.7 & & 9.4 & & 8.9 \\
\hline 伸 び（\%） & & 12.3 & & 2.8 & & 7.8 & & 3.2 \\
\hline シャルピー衝撃值 $\left(\mathrm{kg}-\mathrm{m} / \mathrm{cm}^{2}\right)$ & & 0.62 & & 0.18 & & 0.35 & & 0.16 \\
\hline
\end{tabular}

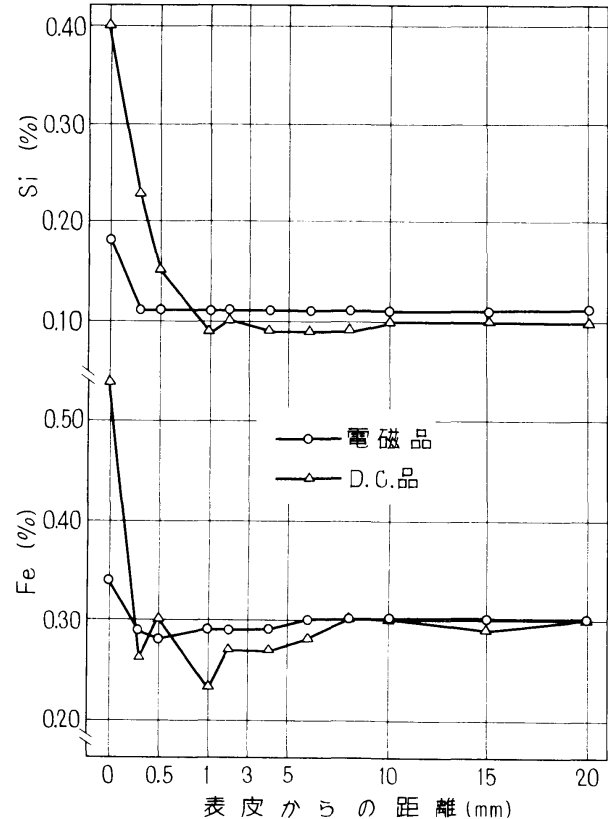

第 9 図 1050スラブ $(400 \times 1320)$ 表皮部での $\mathrm{Si}, \mathrm{Fe}$ の偏析

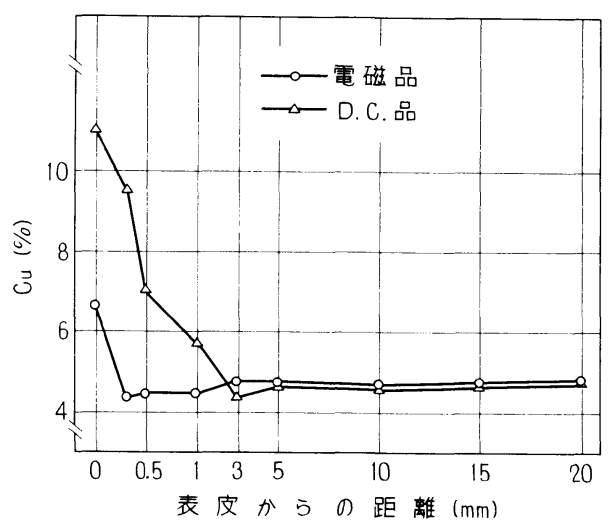

第10図 2014ビレット $(500 \phi)$ 表皮部での $\mathrm{Cu}$ の偏 析

\section{5. おわりに}

電磁法は昔より溶湯の保持, 移動等に利用されてきた 電磁場の理論を基礎に，アルミニウムおよびその合金の

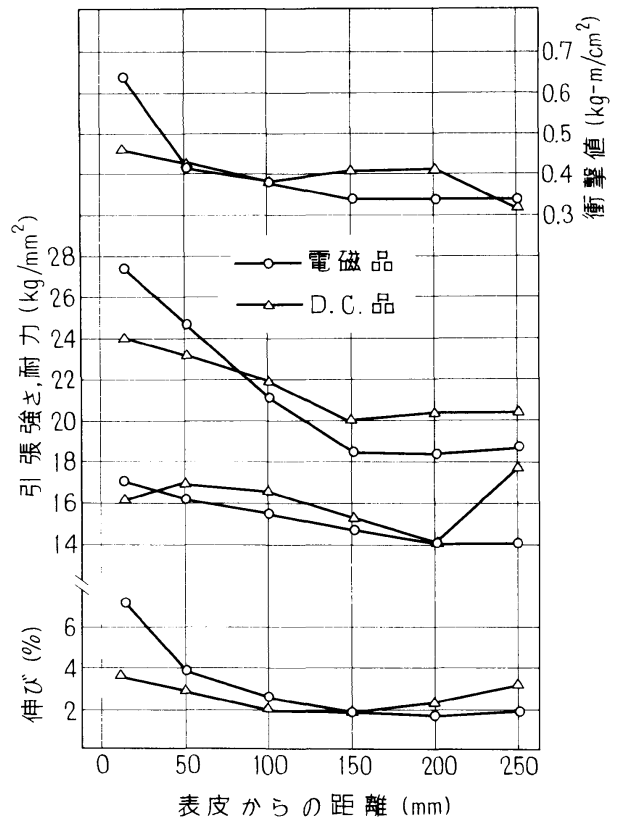

第11図 2014ビレット $(500 \phi)$ における径方向の機 械的性質の分布

加工用鋳塊製造法の 1 つとして開発されたものである。 この方法は今までのD.C.法とは異なり，溶湯は鋳型 と接触せず直接水冷されるため, D.C.法では不可避の 鋳型との接触, エヤーギャップの生成に起因する欠陷を 原理的に排除しうるプロセスであり，得られる鋳塊は表 皮部において優れた品質をもつ。よつて，後続加工に際 し, 面削不要あるいは加工性の向上が期待される。

\section{参 考 文 献}

1) 例えば D. Altenpohl: Aluminium und Aluminium-Legierungen, Springer-Verlag (1965), 117.

2) 椙山，梅田：軽金属，19(1969)，316.

3) Z. H. Getselv: J. Metal, 23 (1971), 38.

4）萩原：Al一ある，(1973)，25，

5) P. P. Hochalov et alii: Sci. J. Non-Ferrous Metal, 11 (1970), 60.

6) G. A. Balakhontsev et alii: Sci. J. Non-Ferrous Metal, 11 (1970), 62. 
7) T. R. Prichett: Light Metal Age, 31 (1973), 9.

8) V. A. Livanov, et alii: Light Metal Age, 32 (1974), 9.

9）エリ.ア．ヴェルテ：溶融金属の電磁鋳込と 電磁処理, 日ソ通信社, (1968)，4，122.

10) ア.デ．アキメンコ, et alii : 回転磁場内の連 続鋳造, 日ソ通信社, (1973), 4 .

11) J. G. Eady et alii: Foundry Trade J. 9 (1972), 603.

12）例えば, 中村仁: 高周波加熱, 恒星社厚生閣, (1970)，121.

13) 日本特許: 特公, 昭46-37267.

14）日本特許: 特開, 昭48-59028.

15) 日本特許 : 特開, 昭48-65118.

16) 日本特許：特公, 昭49-24771.

17) 日本特許：特公, 昭49-26173.

18) 日本特許：特公，昭49-24772.
19) 日本特許：特公，昭49-37493.

20) 日本特許：特公, 昭50-27807.

21） 日本特許：特公，昭50-29696.

22) 日本特許 : 特開, 昭50-80923.

23) 日本特許 : 特開, 昭50-84423.

24) 米国特許 : 3612151 ,

25）清水：軽金属, 20(1970)，577.

26）小菅，水上：軽金属，25(1975)，207.

27）中谷 : 軽金属, 20(1970), 199.

28）潮田，吉村，増山：軽金属, 5(1956-3), 9 .

29) D. Altenpohl: Z. Metallkde., 60 (1969), 576.

30) D. Altenpohl, (村上訳) : 軽金属, 19 (1969), 451.

31）三田村, 杉崎, 青山 : 第 49 回軽金属学会秋期 大会，(1975).

32) 雄谷 : 軽金属, 17 (1967), 298.

33) 中尾：軽金属, 18 (1968), 408. 